\title{
PRF1 wt Allele
}

National Cancer Institute

\section{Source}

National Cancer Institute. PRF1 wt Allele. NCI Thesaurus. Code C97740.

Human PRF1 wild-type allele is located in the vicinity of $10 \mathrm{q} 22$ and is approximately $5 \mathrm{~kb}$ in length. This allele, which encodes perforin-1 protein, plays a role in lymphocyte-mediated cytolysis. Mutation of the gene is associated with T-cell lymphoblastic lymphoma, aplastic anemia, hemophagocytic lymphohistiocytosis familial type 2, autoimmune lymphoproliferative syndrome and other lymphoproliferative disorders, including various forms of lymphoma. 